\title{
MOBILE PASSENGER AND WATER LOADS MOBILE APPLICATION "MY BOAT"
}

\section{${ }^{*}$ Anizio Souza da Cunha, ${ }^{1}$ José Ribamar Moura de Menezes Filho, ${ }^{1}$ Bruno Pereira Gonçalves, ${ }^{1}$ Jean Mark Lobo de Oliveira, ${ }^{2}$ Benevaldo Pereira Gonçalves, ${ }^{3}$ David Barbosa Alencar}

\author{
1Engineering Department of FAMETRO University Center, Amazon-Brazil \\ ${ }^{2}$ Federal Institute of Educational, Science and Technology of Amazonas - IFAM, Brazil \\ ${ }^{3}$ Institute of Technology and Education Galileo of Amazon (ITEGAM), Brazil
}

\section{ARTICLE INFO}

Article History:

Received $17^{\text {th }}$ December, 2019

Received in revised form

$21^{\text {st }}$ January, 2020

Accepted $28^{\text {th }}$ February, 2020

Published online $31^{\text {st }}$ March, 2020

\section{Key Words:}

Rivers; Vessels;

App; Amazonas.

*Corresponding author: Anizio Souza da Cunha,

\begin{abstract}
In the northern region, more precisely in the state of Amazonas there is a great demand for river trips, rivers are the permanent roads that in the water regime puts to the test a whole logistics of passengers and cargo that require strategies for universal comfort of passengers, however the poor organization of ticket purchases ends up becoming a waste of time mainly for people who live far from the center of Manaus-AM, thus delaying these users who are often unable to make their trips. In view of all the problems faced daily by users in relation to the use of river transport in the northern region, more precisely in the state of Amazonas, the idea of developing the "my boat" application was conceived and designed and will in turn facilitate the means of travel by these users to the vessels to their destinations. The application in a simple, fast and safe way, will pass all information to users, such as: departure time, ticket prices, name of vessels available for destination States and Municipalities.
\end{abstract}

Copyright (C) 2020, Larissa Amoroso da Silva et al. This is an open access article distributed under the Creative Commons Attribution License, which permits unrestricted use, distribution, and reproduction in any medium, provided the original work is properly cited.

Citation: Anizio Souza da Cunha, José Ribamar Moura de Menezes Filho, Bruno Pereira Gonçalves et al. 2020. "Mobile passenger and water loads mobile application "my boat"', International Journal of Development Research, 10, (03), 34623-34626.

\section{INTRODUCTION}

Since our state is navigable in more than $90 \%$ of its totality and having a long stretch of rivers, the means of river transportation are increasingly necessary both state and interstate and crossing our rivers. This year it was transported, about 12 million passengers and 4 million tons of cargo values which each year grow more. The data are from the executive report referring to the study on the characterization of the Fluvial Transport of Passengers and Cargo (ANTAQ), published on the same date, February 1 . The study and survey area comprise the main units of the Federation of river flow in the Hydrographic Region of the north of the country. The Ministry of Transport, National Federation of Navigation Companies and Union of River Navigation Companies in the State of Amazonas, announced the disclosure of this research and future implementations to improve this most used means of transport in our region. With these studies, information that was previously unknown to people interested in these means of transport came to light, the results of the second research in partnership FAMETRO with ITEGAM, the objective of this work was to characterize the demand for tickets and transport of goods by river in the Amazon Region, identifying all existing lines and all transport flows, all the fleets of vessels were also identified and, at the same time, a form of evaluations of the waterway terminals was created, thus creating a system that intelligently manages all this information of paramount importance for the river environment. The results indicated that the majority of users of these transports are young people, aged between 18 and 36 years $(57 \%)$, elementary and high school education (52\% have not completed high school) and average monthly family income of $\mathrm{R} \$ 1,775,00$. At least $31 \%$ of respondents were self-employed as an occupation. The main reasons for traveling were: Work, leisure or visiting family and relatives $(32 \%)$ and treatment $(42 \%)$. Today, those who want to travel by boat, to know routes, values and the departure and arrival times of the boats must first find the information among the various sources scattered and then go to the waterway terminal to make the purchase. In view of the facts, the objective of the "Meu Barco" application is to provide river transport users with the best way of traveling and practicality to the city's 
vessels, so that they can have real time through a cellular device or device information regarding your travels. The "Meu Barco" application has the purpose of making it easier for all users who routinely travel along the rivers of the Amazon.

\section{BIBLIOGRAPHIC REVIEW}

In the vast Amazon Hinterland, rivers turn into roads and, in a way, the waterway transport mode becomes the reality for the vast majority of the interior population, several aspects must be considered with regard to the culture of waters, ebb and flow, days of travel and uncomfortable conditions. Like the other means of transport, the waterway system has its own components that directly influence the efficiency of its operations. Among these components are waterways, vessels and terminals. The existing forms of navigation, according to Law No. 9,432 / 1997, which provides for the ordering of waterway transport, are divided into five: port support, maritime support, cabotage, inland and long-haul. Port support and maritime support navigations act as support activities. Cabotage navigation corresponds to the movement between ports or points in the Brazilian territory by sea or between this and inland waterways; inland navigation is carried out on inland waterways, on a national or international route and, finally, long-distance navigation takes place between Brazilian and foreign ports. Considering that this article proposes to address waterway transport in the Amazon Region, the preferred form of navigation during the research is inland navigation in the national territory, through rivers belonging to the Amazon Basin. According to Schneider (2000), inland navigation can occur through natural or artificial waterways, inland from the continent, especially rivers and canals. The waterways that meet the navigation conditions, allowing the transit of large vessels, are called inland waterways. In addition to its own conditions, for a waterway to be safe for navigation, both for vessels and for cargo, passengers and / or crew, there is a need for adequate beaconing and signaling. The navigation potential characteristic of each waterway depends on several factors, and its combination can limit or expand the conditions of navigability, as well as define the standard vessels, regarding their size and their transport capacity, which can take advantage of your potential. The navigation systems existing in the Amazon, according to ANA's Water Resources Notebook (2005), can be classified according to the load capacity and navigability between: rustic vessels, line vessels, ferry trains, trains with more advanced technology. Advanced and ships.

\section{MATERIALS AND METHODS}

In the data collection process, the understanding regarding research and theoretical and practical deepening was highly relevant. First, we needed to understand the research concepts, study how to do them and obtain concrete results, so that we can start our project. We opted to do quantitative and qualitative and Documentary research to collect data and start developing the project, with that it reached a solution to solve our problem of lack of information in the river transport sector. We did a field research inside the FAMETRO University Center, we interviewed people of both sexes and of different ages, it was noticed that there is a great demand for people who travel to other municipalities and need to use river transport, another important point was the lack information related to ticket purchase, vessel names, vessel destinations and departure and arrival times. The application interface being emulated in software will be illustrated in the images below.

The information, options and functions that the application will have, namely:

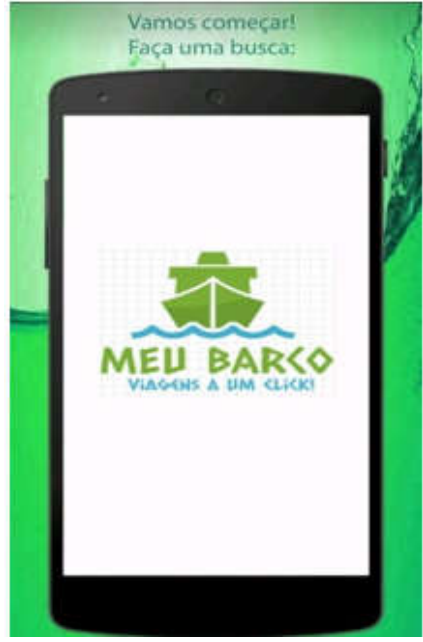

Figure 1. Application startup screen

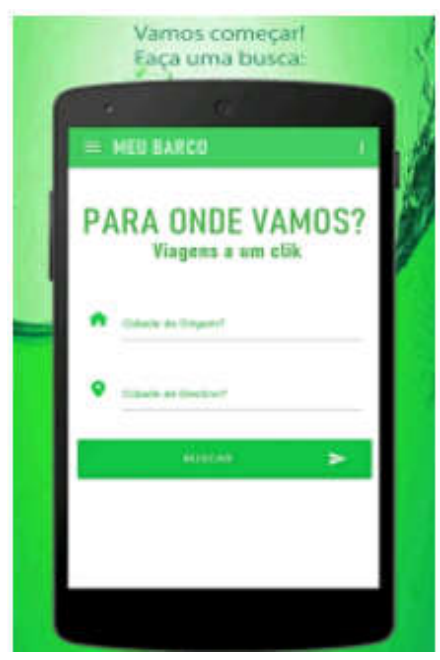

Figure 2. Screen to search for trips
The application is shown as shown in Figures 1 to 4 .

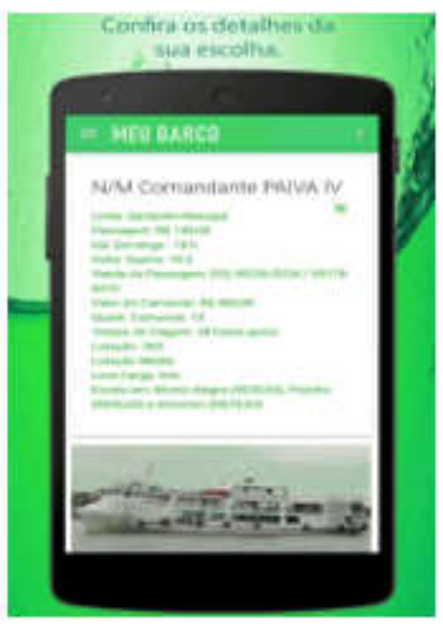

Figure 3. Application details

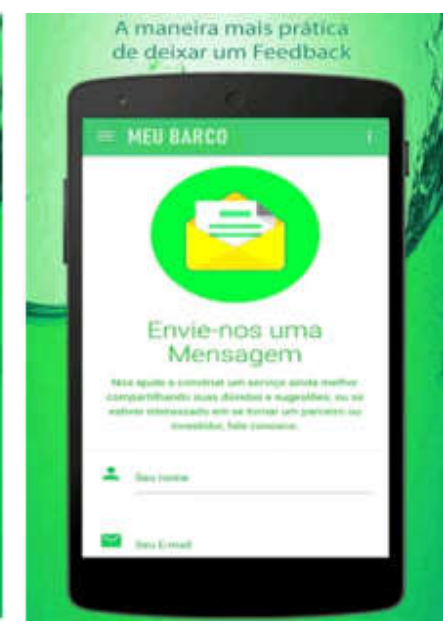

Figure 4. Direct feedback screen
In figure 3 we can say that it is the screen of most interest to the user, because in it we can see all possible information about the boat, values, time, date, time, day and other information:

\section{RESULTS AND DISCUSSIONS}

The municipalities of Manaus, Itacoatiara and Parintins were classified as having excellent accessibility. These municipalities are in a more centralized position among the municipalities that make up the trunk lines of the waterway system. Manaus obtained the best classification among the twenty municipalities considered in the study. Municipalities that are less distant from Manaus have excellent or good accessibility. Table 1 shows the accessibility levels of the municipalities in relation to the distance indicator. It was observed that as the municipalities distance themselves from Manaus, accessibility becomes worse. Coari, Santarém and Tefé ranked well; Caracaraí, Itaituba and Vitória do Jarí were classified as having regular accessibility, the first two of which 
are located in the tributaries of the Amazon River (Rio Branco and Tapajó River), and the third is located on the Jarí River, in the municipality of Amapá. Observing the scenario of statistical data on river trips in Manaus, there is a great demand for river trips, with the research done in the field, precisely at the FAMETRO University Center, where students and teachers answered a survey asking if they often travel.

Table 1. Accessibility and Distance Indicators

\begin{tabular}{|l|l|}
\hline Accessibility Classes & Places \\
\hline Great & Manaus, Itacoatiara e Parintins. \\
\hline Good & Coari, Santarém e Tefé. \\
\hline Regular & Caracaraí, Itaituba e Vitória do Jaraí \\
\hline Bad & $\begin{array}{l}\text { Humaitá, Porto Velho, Macapá, Boa Vista, } \\
\text { Belém e São Gabriel da Cachoeira. }\end{array}$ \\
\hline Terrible & $\begin{array}{l}\text { Tabatinga, Cruzeiro do Sul, Boca do Acre, } \\
\text { Eirunepé e Rio Branco. }\end{array}$ \\
\hline
\end{tabular}

It was observed that as the municipalities distance themselves from Manaus, accessibility becomes worse. Coari, Santarém and Tefé ranked well; Caracaraí, Itaituba and Vitória do Jarí were classified as having regular accessibility, the first two of which are located in the tributaries of the Amazon River (Rio Branco and Tapajó River), and the third is located on the Jarí River, in the municipality of Amapá. Observing the scenario of statistical data on river trips in Manaus, there is a great demand for river trips, with the research done in the field, precisely at the FAMETRO University Center, where students and teachers answered a survey asking if they often travel.

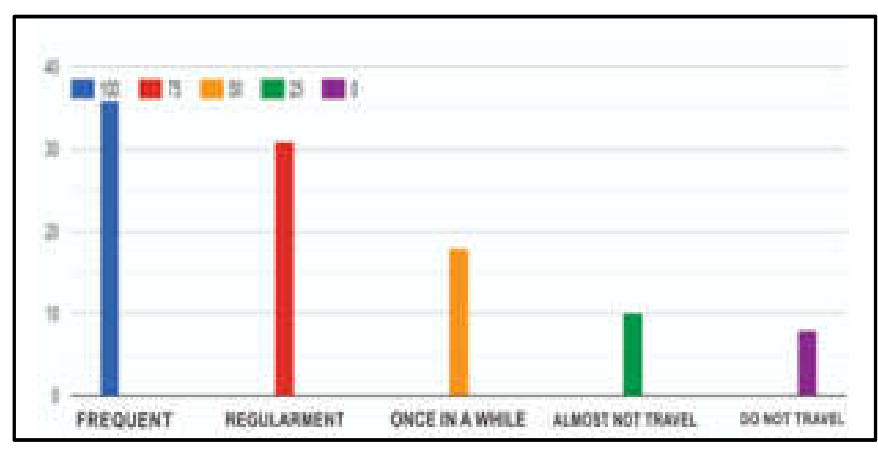

Figure 5. Percentage of people using river transport

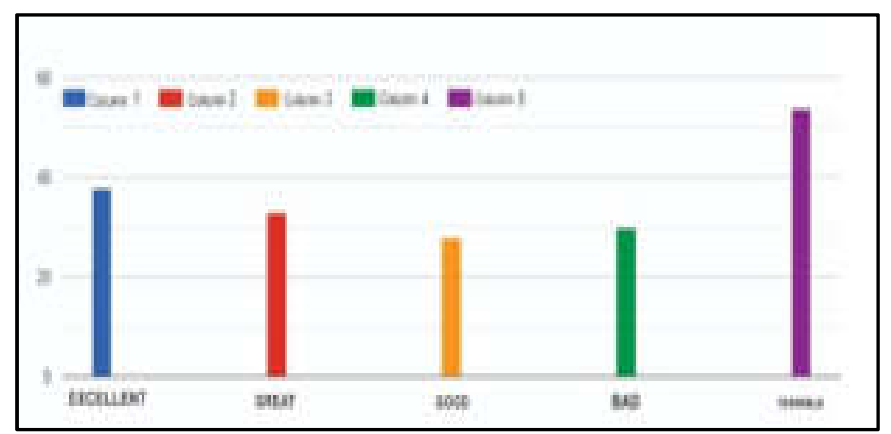

Figure 6. Percentage of satisfaction with the purchase of tickets

Based on Figure 6, we can see that the quality of purchasing river tickets is not the most pleasant, where more than 50\% say that the service for the purchase is terrible.

\section{Conclusion}

Redirecting information about river trips through an app will solve a major problem for people who travel frequently by this means of transport. Due to this fact, a survey was created where it was possible to see that the demands for river trips are enormous, but there is not much information about these trips outside Porto. The application comes with a simple and easyto-use interface containing all the information the passenger needs to complete their trip, so you will not waste time having to move from your location to know how you will travel. It is worth noting that the application is only a prototype, where there are future possibilities to be improved so that it fully meets the needs of the purposes for which it will be developed. Therefore, we intend to continue with the research and development for the improvement of the application, including new applications, always focusing on our objective, to help the river transport user.

\section{Acknowledgments}

To my parents, who despite all the difficulties, helped me in the realization of my dream. To my work friends and research partners, for all the help and support during this very important period of my academic training. To all the people who directly or indirectly contributed to my research.

\section{REFERENCES}

Delbosc, A. e Currie, G. 2010. Transport problems that matter - social and psychological links to transport disadvantage. Journal of Transport Geography, vol. 19, n. 1, pp.170-178.

Geurs, K. T. e Wee, B. 2018. Accessibility evaluation of landuse and transport strategies: review and research directions. Journal of Transport Geography, vol. 12, n. 2, pp.127-140.

Godoy, P. R. C. e Vieira, A. P. 2004. Hidroviasinteriores. Ministério dos Transportes do Brasil. Departamento de Vias Navegáveis. Brasília, Brasil.

Halden, D. 2002. Using accessibility measures to integrate land use and transport policy in Edinburgh and the Lothians. Transport Policy, vol. 9, n. 4, pp. 313-324.

IBGE 2019. Consulta da área territorial e da população. Disponívelem: Www.ibge.gov.br/home/geociencias/ areaterritorial/area.shtm; Data da consulta: 19/12/2019.

Luis, J. A. H. 2002. Temporal accessibility in archipelagos: inter-island shipping in the Canary Islands. Journal of Transport Geography, vol. 10, n. 3, pp.231-239.

Neves, C. (s.d.) A ligaçãohidroviária Barra-Centro. Disponívelemwww.fnttaa.org.br/ligbarracentro.html. Data da Consulta: 02/06/2010.

Pires Jr., F. C. M., Assis, L. F., Silva Jr., J. A. F. da., Antoun, A. R., Pereira, F. de S. e Souza, C. M. 2003. Transporte fluvial de passageirosna Amazônia: regulamentação do setor e segurança da navegação. Segundo Relatório Intermediário de Pesquisa Roadway. Rio de Janeiro: PENO/COPPE/UFRJ.

Pires, F. M. A. 2000. Uma contribuição para análise dos padrões de acessibilidadeem redes rodoviárias. Dissertação (MestradoemEngenharia de Transportes) Universidade Federal do Rio de Janeiro, Rio de Janeiro.

Plano de Desenvolvimento Sustentável da Amazônia Legal 2006 Estudosdiagnósticossetoriais PDSA 2005-2008. Ministério da Integração Nacional. Belém: ADA.

Portugal, L. S. 2018. A Infraestrutura de transportes e suarelação com o desenvolvimentosustentávelna Amazônia. SeminárioInfraestructurasen la Amazonía. Reunión del Banco Interamericano de Desarrollo para orientaraccionesfuturasen la Región. INTAL-Instituto para a Integração da América Latina e do Caribe. Banco 
Interamericano de Desenvolvimento. CEBRI, Rio de Janeiro, Brasil.

Preston, J. e Rajé, F. 2019. Accessibility, mobility and transport-related social exclusion. Journal of Transport Geography. vol. 15, n. 3, pp.151-160.
Raia Jr., A. A. 2000. Acessibilidade e mobilidadenaestimativa de um índice de potencial de viagensutilizando redes neuraisartificiais e sistemas de informaçãogeográfica. Tese (Doutoradoem Engenharia de Transportes), Universidade de São Paulo, São Carlos. 